\title{
What is said and unspoken about the autonomy of a nurse: (dis) continuity in discourses
}

\author{
Entre o dito e o não dito acerca da autonomia do enfermeiro: (des)continuidades nos discursos \\ Entre el dicho y el no dicho acerca de la autonomía del enfermero: (dis)continuidades en los discursos
}

Sabrina Gonçalves Aguiar Soares'
ORCID: 0000-0002-4000-5338

Silviamar Camponogara'

ORCID: 0000-0001-9342-3683

Mara Ambrosina de Oliveira Vargas"

ORCID: 0000-0003-4721-4260

'Universidade Federal de Santa Maria. Santa Maria, Rio Grande do Sul, Brazil.

"Universidade Federal de Santa Catarina. Florianópolis, Santa Catarina, Brazil.

How to cite this article: Soares SGA, Camponogara S, Vargas MAO. What is said and unspoken about the autonomy of a nurse: (dis) continuity in discourses. Rev Bras Enferm. 2020;73(6):e20190401. doi: http://dx.doi.org/10.1590/0034-7167-2019-0401

Corresponding author:

Sabrina Gonçalves Aguiar Soares

E-mail: enfsabrinasoares@yahoo.com.br

EDITOR IN CHIEF: Antonio José de Almeida Filho ASSOCIATE EDITOR: Fátima Helena Espírito Santo

Submission: $05-24-2019$

Approval: 11-21-2019

\begin{abstract}
Objective: to know how autonomy is constituted in the nurse's professional practice in the hospital context. Methods: Qualitative analytical study, based on Foucault's methodological theoretical framework. The empirical material consisted of articles published in the Revista Brasileira de Enfermagem and narrative interviews conducted with 18 nurses from a public hospital in southern Brazil. Data collection took place between December 2017 and May 2018, being analyzed through Foucauldian discourse analysis. Results: Autonomy in the professional practice of nurses goes through the core of knowledge, the political positioning and the working conditions. These factors are revealed as power instruments in the construction of nurse governability. Final Considerations: It is believed that the investment focused on the debate of the nurse's autonomy interfaces could raise new attitudes about professional practice and favor the transformation of nursing practice.

Descriptors: Nurses; Professional Autonomy; Professional Practice; Work; Hospitals.
\end{abstract}

\section{RESUMO}

Objetivo: conhecer como se constitui a autonomia na prática profissional do enfermeiro no contexto hospitalar. Métodos: estudo qualitativo, analítico, assentado no referencial teórico metodológico de Foucault. O material empírico foi composto por artigos publicados na Revista Brasileira de Enfermagem e entrevistas narrativas realizadas com 18 enfermeiros de um hospital público da região Sul do Brasil. A coleta de dados ocorreu entre os meses de dezembro de 2017 a maio de 2018. O discurso foucaultiano foi adotado para a análise de dados. Resultados: a autonomia na prática profissional do enfermeiro perpassa pela centralidade do saber, pelo posicionamento político e pelas condições de trabalho. Esses fatores se revelam como dispositivos de poder na construção da governabilidade do enfermeiro. Considerações Finais: o investimento em espaços voltados para o debate das interfaces da autonomia do enfermeiro pode suscitar novas posturas sobre a prática profissional e favorecer a transformação da prática de enfermagem.

Descritores: Enfermeiros; Autonomia Profissional; Prática Profissional; Trabalho; Hospitais.

\section{RESUMEN}

Objetivo: saber cómo se constituye la autonomía en la práctica profesional de los enfermeros en el contexto hospitalario. Métodos: investigación analítica, cualitativa, basada en el marco teórico metodológico de Foucault. El material empírico consistió en artículos publicados en la Revista Brasileira de Enfermagem y en entrevistas narrativas realizadas con 18 enfermeros de un hospital público en el sur de Brasil. El período de recolección de datos fue de diciembre de 2017 y mayo de 2018. Se adoptó el discurso de Foucault para el análisis de datos. Resultados: la autonomía en la práctica profesional de los enfermeros pasa por la centralidad del conocimiento, el posicionamiento político y las condiciones de trabajo. Estos factores se revelan como dispositivos de poder en la construcción de la gobernabilidad de los enfermeros. Consideraciones finales: la inversión en espacios centrados en el debate de las interfaces de autonomía de los enfermeros puede generar nuevas actitudes sobre la práctica profesional y favorecer la transformación de la práctica de enfermería.

Descriptores: Enfermeros; Autonomía Profesional; Práctica Profesional;Trabajo; Hospitales. 


\section{INTRODUCTION}

Nurse's professional autonomy is presented as a complex subject whose need for more detailed exploration comes from the current configuration of their work. However, it has been progressively gaining new contours, influenced by several factors, but sometimes with practices still focused on the biomedical model ${ }^{(1)}$.

Nurse's professional autonomy is understood when nurses, prepared with moral and intellectual autonomies, enjoy the ability to govern themselves and make decisions freely, establishing their individual or collective practice. Professional autonomy presupposes competence and freedom to make conscious choices, among the possible options ${ }^{(2)}$.

Thus, the way nurses perceive autonomy allows them to be aware of the spaces in which they can act, as well as reflect on their actions to better deal with decisions and choices in the profession ${ }^{(3)}$. Moreover, the critical and reflexive behavior regarding the conditions of possibility of self-government, allows freedom to make decisions within their knowledge and also that tasks are performed in order to generate satisfactory results to their work ${ }^{(4)}$.

Studies show that the professional autonomy of nurses is still limited and sometimes nullified within health organizations $s^{(1,5-6)}$, being an objective to be achieved in the fight for professional achievements in the category ${ }^{(7)}$. From this perspective, this study aims to analyze the conditions of possibilities in which nurses' behavior occurs in relation to professional autonomy in the hospital context, since, according to Foucault(8-9), in the relation knowledge and power, the knowledge is understood as political instruments that aid the mechanisms of power. Thus, all knowledge, whether scientific or ideological, can only exist from the political conditions necessary to create both the subject and the domains of knowledge. The investigation of knowledge should not refer to a subject of knowledge that would be its origin, but to power relations that constitute it. There is no neutral knowledge, all knowledge is political, because all knowledge has its genesis in power relations. All knowledge ensures the exercise of power. Thus, it is understood that knowledge improves nurses' governance practices, enabling the exercise of autonomy.

Thus, the following research question guided the study and allowed to understand the historical (dis)continuities that cross the autonomy in self-government of nurses. What constitutes autonomy in nurses' professional practice in the hospital context?

\section{OBJECTIVE}

To know how autonomy is constituted in the professional practice of nurses in the hospital context.

\section{METHODS}

\section{Ethical aspects}

Because it was a research involving human beings, the ethical aspects were respected in accordance with Resolution n. 466/2012 of the National Health Council.

\section{Methodological theoretical reference}

The study is based on the reflections of theorist Michel Foucault about the constitution of the subject, going through the relations of power and self-care, which reflect the possibility of the nurse to be released and conducted as an ethical and autonomous subject.

\section{Study design}

This is a qualitative study with analytical approach, conducted through Discursive Analysis.

\section{Study setting}

The study setting included the inpatient units of the surgical and medical clinic I and II of a large public hospital in southern Brazil. The institution, scenario of this study, is characterized as a tertiary-level teaching hospital, general, public, serving $100 \%$ by the Unified Health System (SUS), and its purpose is professional training, developing teaching, research and extension through health care to the community.

\section{Data source}

The research was developed in two stages: a documentary an empirical stage. The documentary stage took place through the analysis of articles published in the Revista Brasileira de Enfermagem (REBEn) between 1986 and 2017; The empirical stage occurred through narrative interviews with nurses working in inpatient units of surgical and medical clinic I and II, of a large public hospital in southern Brazil.

\section{Data collection and organization}

In the documentary stage, which took place in December 2017, a detailed virtual investigation of the titles, abstracts, as well as the full reading of the articles published in REBEn was carried out, aiming to select those that discussed the professional autonomy of nurses in the hospital context. We obtained 44 articles with the following inclusion criteria: article with the proposed theme, available online and published from 1986 to 2017. The time limit was due to the approval of Law n. 7498, on June $25^{\text {th }}, 1986$, which provides for the regulation of the Professional Exercise of Nursing. Editorials, thesis and dissertation abstracts and book reviews were excluded.

In an attempt to scan the journal's production on the proposed theme, the selection of articles was not limited by the term autonomy, but rather investigated papers that also used the terms: decision making, ethics, morals, gender and submission. since they reproduce themes that may be related to autonomy. After the selection and separation of the secondary material found, the full reading of the entire documentary body that referred to the object of study was performed. Articles are identified by the letter $\mathrm{A}$, followed by a sequential number.

In the empirical stage, narrative interviews were conducted; these were conducted from April to May 2018, in the research scenario itself, at the interviewee's preferred time and place. Two representatives from each work shift were interviewed, thus 
contemplating the three work shifts, totaling 18 nurses. Requirements for participation in the survey were: that the participant accepted the recording of the interview and had been at the position for at least one year in the sector.

The Criterion for choosing participants was the technique called "snowball", being only the first participant of each unit chosen by drawing the list of nurses working in the study scenario. To close data production, the data saturation criterion was used.

The average duration of interviews was 15 minutes. The interview was guided by the following requests: describe situations that you perceive or understand as exercising autonomy. Give examples. Describe situations that you understand to be limiting in exercising autonomy. Give examples. The answers were recorded on a digital recorder- MP3 player and later transcribed by the researcher. Nurses' statements are identified by the letter $\mathrm{N}$, followed by a sequential number.

\section{Data analysis}

After the secondary material collection and data production stages were concluded, as well as recording and transcribing it in a single document, the discourse analysis began under the Foucauldian perspective, since it is understood that in the nurse's autonomous acting there may be hegemonic discourses, which produce knowledge and truths about self-guidance. Among the concepts that permeate this discourse analysis are the statements, the discourses, the rules of formation, the discursive formation, and the discursive practice as reference for the analysis of the present study. The practice of discourse is considered a set of anonymous, historical rules, always determined in time and space, which defined, at a given time and for a given social, economic, geographical or linguistic area, the conditions for the exercise of the enunciative function ${ }^{(10)}$.

In this sense, what is stated by nurses and what is written in the articles published by nurses are equivalent. In other words, it is not a question of explaining and separating articles and interviews, but of inscribing them within a continuously moving overview. Thus, it was understood, therefore, that a Foucauldian analyzes would allow us to operate with what could be productive from the documentary sources and what is said and what is unspoken by the participants selected for analysis with each of the concepts used and, thus, problematizing meanings that they produced, promote strangeness strategies and make visible a way to conduct themselves, taking into account the autonomy of nurses and their articulation with the historical and political context.

\section{RESULTS}

Based on the data analysis, three discursive formations were defined: "the interface of knowledge in the development of autonomy"; "the interface of working conditions in the development of autonomy"; and "the interface of nurse visibility in the development of autonomy".

\section{The interface of knowledge in the development of autonomy}

Both the articles and the speeches of the participants support the discourse that knowledge is an essential condition for the development of autonomy. In this sense, the excerpts articulate knowledge with decision making, the empowerment of nurses, the actual knowledge of professional practice, the knowledge/ power relationship and the theory/practice dichotomy.

It limits [...] the issue of little understanding, when the nurse has little mastery on the subject, limits decision making. The more empowered and enlightened of the know-how, the more autonomous the nurse becomes. [...] There is a lack of knowledge of professional practice, of going back to books and seeing what our possibility really is. Often, this bumps into the lack of knowledge, that you do not have mastery over what the nurse really would have autonomy to do. (N8)

We do not intend to deny the relationship between knowledge and power, but knowledge alone is no guarantee of power, but knowledge applied to praxis. [...] what often happens is a distancing and even a separation between theory and practice (REBEn, 1992). (A12)

Interestingly, in the following excerpt, the discourse of scientific knowledge is linked to an emerging theme, the issue of governance.

Scientific knowledge [...] allows nurses greater security for clinical and managerial decision making in the context [of work ...]. The conscious and knowledge-based decision-making process supports nurses' governance over nursing practice (REBEn, 2017). (A44)

It is possible to detect discursive regularity in the analyzed articles, both published in the $90^{\prime}$ 's of the $20^{\text {th }}$ century and those published in the first decade of the $21^{\text {st }}$ century, about the fragmentation of the formative process of nursing schools, which does not encourage students to construct political sense, so necessary for autonomous practice. An excerpt refers to the lack of specificity of the nurse's work object and the divergence of professional projection for the academy and the labor market. Another aspect considered is the unspoken in the speeches of nurses; That is, these professionals do not articulate autonomy to the process of building political sense, as stated in the articles.

[...There is] a need for training in nursing schools based on the process of political sense so that future nurses have the view that nursing can and should be an autonomous profession capable of changing their reality (REBEn, 1998). (A17)

[...] professional training that does not promote autonomous practice and the lack of specificity of one's own role [stands out] as a generator of limitations on the exercise of autonomous practice. [...] Much more than a deficiency of the training apparatus, it is believed that there is a mismatch between the goals in which training is developed and those adopted by the market for the performance of new professionals. (REBEn, 2008). (A33)

The qualifications and complementary courses enhance, according to the discourses analyzed, the development of nurses' skills and abilities, which has repercussions on professional recognition, and also, on autonomy. However, it is also reported that when the offered update meets only the institutional interests, it limits the professional's autonomy. 
I always say, sometimes people think I like to be a show off, but I never had a problem here with a doctor, [...] I never had a problem of autonomy, because I always too updating courses. (N6)

Continuing education activities in health institutions play an extremely important role because they not only allow knowledge to be updated and other experiences to be reviewed. However, what happens in many hospital [...] is to limit continuing education activities to the institution's own interests, especially technological and regimental interests. This condition considerably limits the professional autonomy of nurses (REBEn, 2006). (A28)

The search for knowledge through professional qualifications and upgrades enhances the competences and skills of nurses, which results in greater recognition and autonomy in the work (REBEn, 2017). (A44)

\section{The interface of working conditions in the development of autonomy}

The present discursive formation is related to the working conditions of the nurse, which is treated under different aspects. The submission to the hegemonic model of health and the political and economic conditions, the institutionalized action, the disorganization as a social group, the depoliticization, the division and organization of the work object, as well as the comparison to domestic work have power effects on the way of the nurse being constituted as an autonomous subject, being visible in the discourses of the late eighties of the $20^{\text {th }}$ century. These discourses are also reinforced in the first decade of the $21^{\text {st }}$ century, however, the understanding that the opening for the development of creative work and the rescue of patient care need to be considered for the improvement of autonomy permeates in these same discourses

It is a workforce in the production process. It is auxiliary profession, means and not end profession. They do not have their own identity, as the proposed model of care. It is labor submitted to the capitalist market; [...] The disorganization of nursing as a social group is evident. [...] Another important factor that interferes with practice and organization is the level of depoliticization of the category. [...] The central issue of nursing problems internally is related to the division and its object of work. (REBEn, 1988). (A5)

Nursing work can be compared to housekeeping, not accounted for. What is not accounted for, does not have its economic value highlighted. What does not have its economic value highlighted, does not have, in a model such as ours, its rights respected. [...] Social work alone did not represent freedom and autonomy (REBEn, 1988). (A8)

Unfortunately, what is observed in our reality is the supremacy of institutionalized acting, causing delimitation of professional performance, rather than stimulating creative acting for professional improvement. And this is a deficiency that has been present since undergraduate nursing school (REBEn, 2009). (A34)

Nursing is still very submissive to the hospital hierarchy, the mechanistic paradigm and the capitalist mode of production. The most important consequence of this submission [...] is the restriction of the institutionalization of nursing knowledge autonomy, which is related to the broad dimension of the care process. [...] Responsibility for care is present as an autonomous activity, but it is not considered a priority. [...] This misleading of caregiving action, besides translating the loss of autonomy in the knowledge plane in relation to the person in care and the nursing team, is entirely consistent with the hegemonic mechanistic paradigm in the context of a modern hospital. (REBEn, 2006). (A28)

In statements from the late 80 's and $90^{\prime}$ s of the $20^{\text {th }}$ century, are present in their discourses aspects such as the relationship of domination and subservience between the nursing team, the competition of knowledge, as well as the unpreparedness for conflict management and use of some strategies by nurses to face resistance among the team. Still, in the discourses of the first decade of the $21^{\text {st }}$ century, these same ways of power attitude permeate the practice of nursing.

Nurses have always required throughout their existence strong support [...from] the nursing staff-hierarchically and technically subordinated to those with a university degree. Due to this fact nursing has become a profession that experiences in its own internal structure, strong competition, not only in the division of labor but especially in the dispute for the nursing services market, hindering its effective professionalization. (REBEn, 1999). (A18)

Two dimensions that exist in nursing work determine and explain the conflict situation found in the category, since knowledge and know-how, that is, intellectual work and the physical work is for different individuals, causing inequalities of social appreciation and intensifying conflicts existing in the nursing team (REBEn, 1988). (A6)

The nurse/technician/nursing assistant relationship, despite being from the same professional team, is permeated by the relationship of domination, control and subservience. These professionals, who previously answered directly to the doctor, and even being a relationship of domination, there were no conflicts, once the knowledge was not compatible. As they began to respond to the nurse, hostilities began to emerge and the struggles set in (REBEn, 2006). (A29)

It can be pointed out as strategies, used by nurses, to cope with power relations: the exposure of their opinion and the adoption of a firmer posture, facing the manifestations to the resistance to changes by some employees (REBEn, 2001). (A20)

The following statement, expressed by the nurse, shows the discontinuity between the discourses presented above, since it points the issue of moral harassment as a mechanism of intimidation, a fact that, besides generating discomfort and fear of taking over a situation, interferes with their professional performance.

The nursing staff, especially the technicians when we ask them for chores that are their attributions, [...] many times, they contest saying that this is moral harassment, that we are "picking" on them and that ends up, not making them afraid of reporting, but apprehensive instead, so we end up leaving for the supervisor to talk later. [...] I realize that sometimes they, not that they should not be, but it seems that they are very empowered to intimidate the nurse. [...] And this is something that bothers me, especially if I need to solve something or correct them early in the day, and then they have an attitude with me for the rest of the day. (N5)

Another nuance, evidenced in the following statement, is the tacit hierarchy, where the nurse, in his/her work shift, has autonomy in decision making and problem solving, even though 
there is a head nurse in the sector, a fact that makes it a reference for nursing staff. However, a statement contradicts that nurses cannot exercise autonomy due to their actions being linked to the organizational structure.

It is important to emphasize that the organizational structure is inserted in a political, social and economic context and, although impacting nursing practice, does not prevent nurses from making decisions related to their work process.

Although there is the head nurse, we know that the nursing staff always has the shift nurse as a reference. So, they always report themselves to the nurse. (N1)

Although there is a formal discourse that nurse managers have autonomy to make decisions related to their work, in professional practice nurses find organizational barriers, a portrait of a political system in which senior managers have partially conflicting goals (REBEn, 2015). (A41)

Several statements support the discourse on factors limiting the autonomy of nurses in service management, namely: lack of human and material resources, dependence on other services, absence of medical prescriptions, segregation between nurse/doctor, as well as lack of institutional support in enforcing employee sanctions and bed management in the unit. Regarding the management of beds, a discourse disagrees with the regularity presented, as it makes visible the Internal Bed Management Center (NIR) as a partner in the management of the unit. It corresponds to the Center responsible for managing access to care services for SUS users, internal and external, of the University Hospital under study, through the organization and management of internal flow, aiming to optimize the use of installed capacity.

Bed management is not our responsibility, it is NIR's, but we have the autonomy to help manage beds. We often organize all the isolation beds and then let them know, because what they want is to know how many vacant beds will be left. (N7)

What is limiting me is the issue of bed autonomy, as bed management has expanded to all units, we have lost some of this autonomy of managing beds, patients, clinics. (N15)

What could be improved is the segregation of doctors and nurses and also the issue of managing the team. We work a lot with awareness here, [...] which is a good way, but I have to say that you often need some extra support to [...] ask more for the employee. [...] There is also [...] someone who makes the link between [nursing] and [medical] heads [...] for better autonomy regarding the patient, for example, the patient will do a tomography, we only find it out at the moment the tomography sector makes contact, hey I'm also in charge, I'm responsible too. (N7)

Professional satisfaction is also linked to the autonomy of nurses, as shown in the articles analyzed. Thus, the following statements are open for discussion:

Aspects such as the deficiency related to human and material resources, the institution's own physical structure, which does not have adequate accommodation fornursing professionals to eat and/orrest, contributes to the dissatisfaction of the workers (REBEn, 2005). (A26)
To invest in factors that improve the environment, considering relational and autonomy aspects, and especially the structural aspects of nursing participation in the control of practices, decision making, management and organizational support for work, as well as working time in the ICU and availability to work, brings professional satisfaction (REBEn, 2017). (A42)

Given the context presented, it can be inferred that investments in the improvement of working conditions and relationships, especially in the nursing practice environment, contribute to the nurse's autonomy and satisfaction. It is noteworthy that the nurses interviewed did not articulate autonomy to professional satisfaction.

\section{The interface of nurse visibility in the development of autonomy}

Another interface of nurses' professional autonomy, pointed out by the articles, is the visibility of the profession in front of the health team and society. At the end of the $20^{\text {th }}$ century, it is possible to identify discourses that address influential aspects in the invisibility of nurses and, concomitantly, in their professional autonomy, namely, the lack of knowledge of the attributions, the distancing of their work object and the delegation of their professional practice, the lack of scientific knowledge production, the political fragility, the need for appreciation, the different degrees of training among the nursing staff and the dependence on paid work in health institutions.

At the beginning of the $21^{\text {st }}$ century, some discourses are perpetuated and others are revealed as discontinuity by pointing out that autonomy can be effected by those professionals who, in their daily work, develop their activities with creativity, readiness, confidence, experience, will to face challenges, as well as co-participation in decision making and knowledge about the different scenarios of nursing practice. In addition, it is possible to highlight the non-articulation of autonomy to professional visibility by nurses, as in the articles' excerpts.

No nurse has doubts about what is expected from her in terms of posture and personal appearance, but few know what her real duties are. Commitment to the needs of the system, among others, made the nurse a professional away from her own work object, linked to the control of other team members, through the management, no longer produces the knowledge necessary for her practice, which no longer it is hers because it is delegated. This is how the professional nurse is: without identity, not producing a knowledge that moves the profession to meet the needs of the majority of the population, fragile and politically unstructured (REBEn, 1989). (A9)

Another relevant aspect deals with the different degrees of training of the Nursing team, of which society, in general, does not notice the difference when are being cared by these professionals (REBEn, 2005). (A25)

If we want an autonomous profession, free from the command of others, working interdisciplinarity, we need to create different means than already exist to transform our practice and be recognized by society. [...] We consider that this can prove that there are instruments, such as creativity, and characteristics, such as the willingness to face challenges, that contribute to the development of an autonomous professional practice (REBEn, 1998). (A17) 
The phenomenon of professional visibility appears as emerging from the manifestations of technical-scientific knowledge on the part of being a nurse, co-participation in decision making regarding the client or the management of the unit and in the humanized way of caring. [...] Attributes such as initiative, experience and confidence that he/she transmits to the team were identified as visibility factors (REBEn, 2007). (A31)

Given the above, it was possible to verify that the autonomy in the nurse's professional practice goes through the centrality of knowledge, the political positioning and the working conditions.

\section{DISCUSSION}

In the discussion of the discursive formation "the interface of knowledge in the development of autonomy" the importance of nurses constituting themselves as knowledge subjects and sociopolitical subjects is discussed, since knowledge associated to practice favors conditions for the subject's empowerment as well as contributes to the legitimacy and visibility of the profession.

It is worth noting, regarding this subject, that the interviewed nurses do not link autonomous practice to political issues, as shown in the articles. This may possibly be due to the fact that the nurse does not identify him/herself as a socio-political subject, as well as not recognizing his/her space of action as an ethical-political space propitious to ethical performance.

A similar result was found in the literature, which, in a study that aimed to construct and validate a nurses' political competence attributes guide, it was observed that nurses still have a limited and fragmented perception of what political competence is, and there is articulation of it with practice, which characterizes a relatively unprepared professional class, with vocation directed to know how to perform the technique ${ }^{(11)}$.

It was also evidenced, in the results of this research, that the fragmentation of the professional training and the disharmony between the purposes about the nurse's performance for teaching and the labor market contribute to the distancing of the nurse as a political subject. On the other hand, the excerpts pointed out the professional improvement through courses and qualifications, as a means of granting conditions for an ethical conduct of the nurse.

It is considered that the moment of graduation is opportune and fruitful to work and develop, in the student, the political competence, because it is during the training that the figure of the future professional is built and enhanced, adding values and many diverse knowledges. Although the technical dimension makes up a large part of the curricular structure of nursing courses, the health system needs and demands from professionals, political and ethical skills that favor the recognition of nurses as complete and qualified professionals ${ }^{(12)}$.

Regarding the dissonance between university education and the labor market, this differentiation often occurs because academia seeks to train thinking professionals with strong ability to practice their citizenship. Whereas, the labor market targets individuals with good practical ability, speed and precision in performing the tasks assigned to them ${ }^{(13)}$.

In this perspective, researchers ${ }^{(14)}$ highlight the need for reformulation of academic education, not only regarding content review, but also in the construction of strategies for students integration into the world of work, forecasting what they will find and how to act in the face of this transition. It is necessary to think about a work-oriented training that integrates theoretical and practical skills, attitudes and ethical values, while also providing general and specific knowledge $\mathrm{e}^{(15-16)}$.

In summary, it is argued that the effectiveness of professional autonomy to the knowledge domain produces truths that subjectify and govern the nurse's way of being and acting, legitimizing the relationship of knowledge/power, which constitutes the nurse subject. Thus, it is understood that knowledge assigns empowerment to the nurse subject, allowing the subjectification of a true discourse in a practice and an acting of oneself about oneself ${ }^{(8)}$.

The constitution of the nurse as an autonomous subject also derives from the conditions under which this professional develops his/her work, since the care practices in the hospital context are permeated by established truths and power relations; which can be seen through the discursive formation "the interface of working conditions in the development of autonomy".

By analyzing the truths of this discursive network, one can see the continuity of working conditions, which negatively affect the nurses' self-government. The truths that circulate, according to the discourses, point to the predominance of institutionalized and subjected actions, which support the hegemonic model of health, as limiters of ethical action.

In a study aimed at reflecting on the professional autonomy of nurses in the context of the biomedical care model, the authors concluded that, in this context, the professional autonomy of nurses is limited and conditioned by the medical demands ${ }^{(6)}$. It is noteworthy that the effectiveness of the nurse's professional autonomy will occur from the construction of a field of selfknowledge that is not a subsidiary of medical practice.

The apparent permissiveness of nurses' ways of being and acting in the hospital context, associated with the distance from their work object, result in demotivation, tensions and conflicts. Thus, it emerges from the discourses, as an ethical possibility of the subject nurse, the rescue of the practices of direct care, as these are not performed in their fullness in the daily routine of the profession.

The discourses also reveal the internal conflicts that exist between the nursing team, which are related especially to the competition of knowledge and the lack of preparation of the nurse in conflict management. In this sense, it is clear that the mid-level professional does not accept to receiving orders and being pressed in their duties, as well as the higher-level professional recognizes the resistance of subordinates in this behavior and judges it as something harmful to the internal relationship of the team ${ }^{(17)}$. Therefore, it is argued that the hierarchization of knowledge is a source that generates conflicts between professionals, negatively affecting nurses as subjective.

Service management by nurses is also a highlighted among the discourses analyzed. From this perspective, understanding that management and care tools are interconnected will allow nurses to restructure and act integrally in the various scenarios of nursing practice. From a "new" thought about what are the attributions of nursing, it is possible to improve the practice and thus highlight the uniqueness of nursing performance as a care profession ${ }^{(18)}$, favoring professional satisfaction and autonomous practice. 
The characteristics of the environment influence the results of professional satisfaction and nursing care practices ${ }^{(19)}$. Therefore, investing in factors that improve the environment, considering relational and autonomy aspects, and especially the structural aspects of nursing participation in the control of practices, decision making, management and organizational support for work, promotes professional satisfaction ${ }^{(20)}$, and also enables the appreciation of the acting and the professional visibility of the nurse.

In this scenario, the discursive formation "the interface of the nurse's visibility in the development of autonomy" is discussed. The literature shows a fragile social valorization and media visibility of nursing work ${ }^{(21)}$, a fact that contributes to the strengthening of the power relations existing in the work relations of this subject.

When evaluating the work of nurses in a hospital setting under a Foucauldian view, it is clear that the institutional forces generally show more strength than the initiatives of the worker ${ }^{(22)}$. It is inferred that this occurs especially because the hospital is an institution permeated by rules, routines and hierarchies, which favors the power relations to be produced and reproduced ${ }^{(23)}$. Thus, it is understood that nurses' work in the hospital environment is permeated by ways of power exercise that normalize their behavior, make it difficult for them to reinvent themselves as autonomous subjects and aesthete, since the hospital structure is revealed as a nucleus of strong domination ${ }^{(22)}$. Even so, spaces of resistance are visible, capable of weakening the traditional hegemony in health institutions, allowing nurses to have their governance reinvented.

\section{Study Limitations}

The limitations in this study are recognized because it was developed only in the hospital locus. Thus, it is suggested new studies with this thematic focus both in the hospital area and in primary health care, in order to provide the deepening of this knowledge according to different realities.

\section{Contributions to the Field}

This study is relevant for the Nursing area, since it will subsidize other research, aiming to deepen the debate on the issues associated with the different ways of being a nurse in the hospital environment, as well as assisting the nurses to rethink their professional practice, in order to change its reality and thus legitimize ethical self-care and a more autonomous professional practice.

\section{FINAL CONSIDERATIONS}

The discourses that runs as truth show knowledge as a sinequa non condition for the development of nurses' autonomy in the hospital environment, as well as the interfaces of working conditions and visibility exert power over the autonomous practice of nurses.

Despite the multiple factors that contribute to the subjection of nurses in the hospital service, aspects capable of enhancing the autonomous practice of this professional were identified, this way, mobilizing the power relations established in their work environment. It is believed that the investment in spaces focused on the debate on the interfaces of nurse autonomy, both in academia and in health institutions, it could raise new attitudes and, thus, favor the transformation of nursing practice. In addition, it could transmute the power relations established in this scenario and enhance the exercise of nurse autonomy.

\section{FUNDING}

Coordenação de Aperfeiçoamento de Pessoal de Nível Superior.

\section{REFERENCES}

1. Santos El, Alves YR, Gomes AMT, Silva ACSS, Mota DB, Almeida EA. Social representations of nurses' professional autonomy among nonnursing health personnel. Rev Enferm UERJ [Internet]. 2015;23(4):481-7. doi: 10.12957/reuerj.2015.17944

2. Berti HW, Braga EM, Godoy IW, Spiri C, Bocchi SC. Movement undertaken by newly graduated nurses towards the strengthening of their professional autonomy and towards patient autonomy. Rev Lat Am Enferm. 2008;16(2):184-91. doi: 10.1590/S0104-11692008000200003

3. Kraemer FZ, Duarte MLC, Kaiser DE. Autonomia e trabalho do enfermeiro. Rev Gaúcha Enferm. 2011;32(3):487-94. doi: 10.1590/ S1983-14472011000300008

4. Rigue AC, Dalmolin GL, Speroni KS, Bresolin JZ, Rigue AA. Work Satisfaction: Perception of Nurses of a University Hospital. Cogitare Enferm. 2016;21(3):01-9. doi: 10.5380/ce.v21i3.46199

5. Baykara ZG, Sahinoglu S. An evaluation of nurse's professional autonomy in Turkey. Nurs Ethics. 2014;21(4):447-60. doi: $10.1177 / 0969733013505307$

6. Melo CMM, Florentino TC, Mascarenhas NB, Macedo KS, Silva MC, Mascarenhas SN. Professional autonomy of the nurse: some reflections. Esc Anna Nery. 2016;20(4):e20160085. doi: 10.5935/1414-8145.20160085

7. Santos El, Alves YR, Silva ACSS, Gomes AMT. Professional autonomy and nursing: representations of health professionals. Rev Gaúcha Enferm. 2017;38(1):e59033. doi: 10.1590/1983-1447.2017.01.59033

8. Foucault M. A hermenêutica do sujeito. 3. ed. São Paulo: Martins Fontes; 2014. 518p.

9. Foucault M. Microfísica do poder. 5. ed. Rio de Janeiro: Paz e Terra; 2017. 432p.

10. Foucault M. A Arqueologia do Saber. 8. ed. Rio de Janeiro: Forense Universitária; 2016. 254p. 
11. Melo WS, Oliveira PJF, Monteiro FPM, Santos FCA, Silva MJN, Calderon CJ, et al. Guide of attributes of the nurse's political competence: a methodological study. Rev Bras Enferm. 2017;70(3):526-34. doi: 10.1590/0034-7167-2016-0483

12. Bellaguarda MLR, Padilha MI, Pereira Neto AF, Pires D, Peres MAA. Reflexão sobre a legitimidade da autonomia da enfermagem no campo das profissões de saúde à luz das ideias de Eliot Freidson. Esc Anna Nery. 2013;17(2):369-74. doi: 10.1590/S1414-81452013000200023

13. Santos El, Gomes AMT, Oliveira DC, Marques SC, Bernardes MMR. Challenges and confrontations in care by nurses: a study of social representations. Online Braz J Nurs [Internet]. 2014;13(2):207-18. doi: 10.5935/1676-4285.20144365

14. Souza e Souza LP, Silva WSS, Mota EC, Santana JMF, Siqueira LG, Silva CSO, et al. Os desafios do recém-graduado em Enfermagem no mundo do trabalho. Rev Cuba Enferm [Internet]. 2015 [cited 2018 Oct 15];30(1):4-18. Available from: http://www.revenfermeria.sld.cu/index.php/ enf/article/view/127/79. Portuguese.

15. Mota DB, Gomes AMT, Silva ACSS, Ramos RS, Nogueira VPF, Belém LS. Representações sociais da autonomia do enfermeiro para acadêmicos de enfermagem. Rev Cuid. 2018;9(2):2215-232. doi: 10.15649/cuidarte.v9i2.528

16. Georgiou E, Papathanassoglou EDE, Pavlakis A. Nurse-physician collaboration and associations with perceived autonomy in Cypriot critical care nurses. Nurs Crit Care. 2017;22(1):29-39. doi: 10.1111/nicc.12126

17. Araújo MPS, Medeiros SM de, Quental LLC. Interpersonal relations among nursing staff: fragilities and strengths. Rev Enferm UERJ [Internet]. 2016;24(5):e7657. doi: 10.12957/reuerj.2016.7657

18. Siewert JS, Rodrigues DB, Malfussi L, Andrade SR. Management of Integral Care in Nursing: reflections under the perspective of Complex Thinking. Rev Min Enferm. 2017;21:e-1047. doi: 10.5935/1415-2762.20170057

19. Bacha AM, Grassiotto OR, Gonçalves SP, Higa R, Fonsechi-Carvasan GA, Machado HC, et al. Job satisfaction of nursing staff in a university hospital. Rev Bras Enferm. 2015;68(6):819-26. doi: 10.1590/0034-7167.2015680619i

20. Oliveira EM, Barbosa RL, Andolhe R, Eiras FR, Padilha KG. Nursing practice environment and work satisfaction in critical units. Rev Bras Enferm. 2017;70(1):73-80. doi:10.1590/0034-7167-2016-0211

21. Fonseca LF, Silva MJP. Desafiando a imagem milenar da enfermagem perante adolescentes pela internet: impacto sobre suas representações sociais. Ciênc Cuid Saúde. 2012;11(Supl):54-62. doi: 10.4025/cienccuidsaude.v11i5.17052

22. Rezende MCC, Ferreira Neto JL. Processos de subjetivação na experiência de uma equipe de enfermagem em oncologia. Psicol Saúde [Internet]. 2013 [cited 2018 Jun 09];5(1):40-8. Available from: http://pepsic.bvsalud.org/pdf/rpsaude/v5n1/v5n1a07.pdf

23. Baptista MKS, Santos RM, Duarte SJH, Comassetto I, Trezza MCSF. O paciente e as relações de poder-saber cuidar dos profissionais de enfermagem. Esc Anna Nery. 2017;21(4):e20170064. doi: 10.1590/2177-9465-EAN-2017-0064 